\title{
Jaarverslag Commissie Klachtenbehandeling Aanstellingskeuringen
}

\section{Bas Sorgdrager}

De Commissie Klachtenbehandeling Aanstellingskeuringen (CKA) heeft als doelstelling om het kennisniveau over de Wet op de medische keuringen (Wmk) te verbeteren, en mede daardoor te voorkomen dat mensen ten onrechte medisch worden gekeurd bij het aanvaarden van een nieuwe functie. De CKA is uitsluitend bevoegd te oordelen over aanstellingskeuringen. Jaarlijks brengt de CKA een jaarverslag uit met leerzame casuïstiek. Een voorbeeld.

Eén van de vier klachten die de commissie heeft behandeld, gaat over gezondheidsvragen. In deze zaak gaat het om een psychologisch onderzoek (PO). Als in dat kader gezondheidsvragen worden gesteld, valt dit $\mathrm{PO}$ onder de werkingssfeer van de Wet op de medische keuringen en is het aan te merken als een aanstellingskeuring. Een psycholoog vroeg een sollicitante tijdens een selectieassessment hoe zij in het verleden was omgegaan met bepaalde moeilijkheden. Volgens de werkgever ging het er daarbij alleen om te achterhalen hoe zij zich had gedragen en niet om de gevolgen voor haar gezondheid. Er ontstond echter een gesprek over haar ADHD en migraine en de medicatie die ze gebruikte. Dit leidde tot een negatief advies van de psycholoog. De CKA verklaarde de klacht ontvankelijk. De psycholoog is op grond van de Wmk niet bevoegd om tijdens een assessment vragen te stellen of inlichtingen in te winnen over de gezondheidstoestand van de keurling.

Wanneer in het kader van een PO op een zeker moment ook informatie over de gezondheid van sollicitant naar boven komt zonder dat de psycholoog een gezondheidsvraag stelt, is de CKA van oordeel dat een psycholoog op dat moment de sollicitant er op moet wijzen dat wat aan de orde wordt gesteld niet valt onder de reikwijdte van het PO. De psycholoog dient dan niet verder op de informatie die is gedeeld in te gaan en deze informatie niet te gebruiken in zijn afweging en voor zijn advies. Indien de door de sollicitant verstrekte informatie over de gezondheid relevant is voor de vraag naar zijn geschiktheid voor de functie, moet de psycholoog het onderzoek overdragen aan een bedrijfsarts. De bedrijfsarts kan in tegenstelling tot de psycholoog ook aanvullende informatie opvragen bij de behandelend arts(en) van betrokkene.

Het jaarverslag verschijnt uitsluitend digitaal. Vanuit https://www.aanstellingskeuringen.nl/publicaties/ jaarverslagen/2017.aspx kunt u doorklikken naar webpagina's met meer informatie en achterliggende documenten.

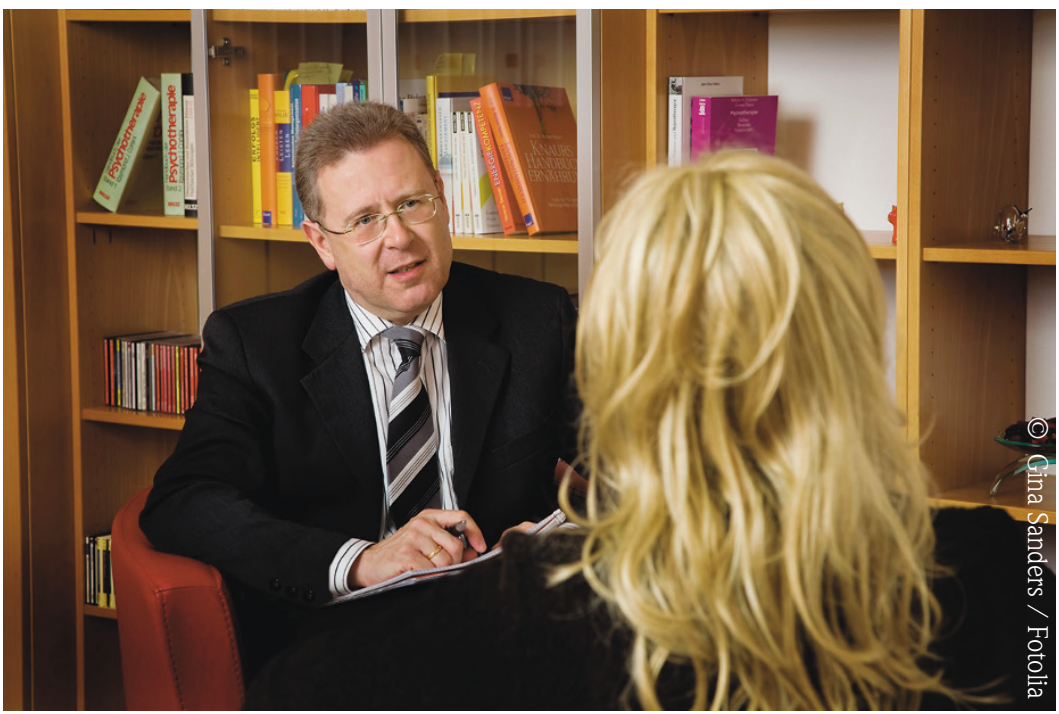

